\title{
Egy földikutya-áttelepítés tanulságai
}

\author{
Schneider Viktor ${ }^{1}$, Ruzsa János², Czabán Dávid² és Németh Attila ${ }^{3}$ \\ ${ }^{1}$ Szent István Egyetem, Mezögazdaság-és Környezettudományi Kar, \\ 2100 Gödöllö, Páter Károly u. 1. \\ ${ }^{2}$ Független kutató \\ ${ }^{3}$ Magyar Természettudományi Múzeum, \\ 1088 Budapest, Baross u. 13. \\ E-mail:viktor.schneider95@gmail.com
}

\begin{abstract}
Összefoglaló: A délvidéki földikutya legnagyobb egyedszámú ismert állományának otthont adó Bajai földikutya-rezervátum közelében, szükségessé vált egy kisebb töredékállomány kimenekítése egy tervezett napelem park építési területéröl. A 2017-ben végrehajtott akció során tíz példány áttelepítésére került sor a védett terület egy, az akció idején földikutyák által addig nem lakott részére. A transzlokációt követően egy éven át nyomon követtük a létrehozott új töredékállomány sorsát. Az új állomány megfigyelési eredményeinek valamint egy korábbi, már lezárult és sikeresnek ítélt áttelepítés monitoring adatainak összevetése alapján kedvezőtlen trend rajzolódott ki. A befogási és elengedési helyszín különféle ökológiai változóinak (domborzati, talajtani és növénytani) összehasonlítása során a kijelölt áttelepítési helyszín esetleges alkalmatlansága is felmerül. A bemutatott eredmények hozzájárulhatnak a jövőbeli hasonló áttelepítési akciók sikerességéhez.
\end{abstract}

Kulcsszavak: Nannospalax (leucodon) montanosyrmiensis, élőhelyi-igény, élőhely-alkalmassági vizsgálat, monitoring, Baja

\section{Bevezetés}

A biológiai sokféleség drámai mértékủ és mind gyorsuló ütemü csökkenése talán a legkritikusabb környezeti probléma, mellyel napjainkban az emberiségnek szembe kell néznie (Ceballos et al. 2010, 2015, Barnosky et al. 2011, Pereira et al. 2010, Pimm et al. 1995, Vida 2018). Bár a (bio)diverzitás szakirodalomban fellelhetö tudományos igényü meghatározásának, valamint lehetséges mérési módjainak száma elrettentő mértékü (Vida 2018, Tóthmérész 2018), a legszembetünőbb biodiverzitási egység egyértelműen a biológiai faj (Vida 2018). A földi fajok riasztó mértékü fogyatkozása ugyanakkor, melyet mind több tudományosan megalapozott vizsgálat eredménye támaszt alá (Ceballos et al. 2017, Hallmann et al. 2017) komoly aggodalomra ad okot. A vadonélő fajok egyedszámának és elterjedési területének nagymértékü csökkenése (Ceballos et al. 2017) a fajok 
többségét a veszélyeztetett kategóriák valamelyikébe sodorja. Ezeket a globálisan megfigyelhetö folyamatokat ezidáig érdemben nem sikerült orvosolnia az emberiségnek; a kedvezőtlen hatások következményei többnyire nem vagy csak kivételes erőfeszítésekkel állíthatók helyre (Vida 2018). A veszélyeztetett fajok között sok olyan nehéz helyzetbe került, hogy hosszútávú fennmaradásához minden még létező populációja, sőt olykor minden még élő példánya elengedhetetlen fontosságú. Ilyenkor az élőhelyek védelme mellett a populációk számának gyarapítására nyílhat lehetőség, rosszabb esetben az eredeti élőhelyén megőrizhetetlen állomány kimenekítése válhat szükségszerüvé. Ezért is alakulhattak a visszatelepítések és áttelepítések a gyakorlati természetvédelem széles körben használt módszereivé (Pullin \& Bajomi 2008). Már az 1980-as években, csupán Észak-Amerikában, évente 700 áttelepítési program valósult meg (Griffith et al. 1989). Az IUCN (Természetvédelmi Világszövetség) áttelepítésekre szakosodott szakosztályának (Reintroduction Specialist Group) adatbázisa szerint közel 500 állatfajt érintenek a már zajló vagy a közeljövőre tervezett áttelepítési akciók (Seddon et al. 2007).

Hazánk talán legveszélyeztetettebb emlősei, a fokozottan védett nyugati földikutya kisfajok esetében is a fentebb említett rendkívül kedvezőtlen helyzet állt elö, nevezetesen, hogy minden még létező állományuk szükséges fajuk hosszú távú fennmaradásának biztosításához. Bár e talajlakó rágcsálók egykor széles körben elterjedtek voltak Magyarországon, élőhelyeik átalakításának és megszünésének következtében kritikus helyzetbe kerültek (Németh et al. 2013/a). A legfrissebb kutatási eredmények szerint hazánk területén három földikutyafaj fordul elö, melyek Kárpát-medencei endemizmusok (Csorba et al. 2015, Németh et al. 2013/a). Ezek mindegyike veszélyeztetett, de a legkritikusabb a délvidéki földikutya, Nannospalax (leucodon) montanosyrmiensis helyzete, mely kizárólag Magyarországon és Szerbia Vajdaság tartományában honos, és összes egyedszáma nem haladja meg az 1000 példányt (Csorba et al. 2015). A délvidéki földikutya egy olyan leszármazási vonalat képvisel, mely az összes eddig vizsgált európai földikutyától korán, mintegy 2 millió éve elkülönült és sajátos fejlődési utat járt be (Hadid et al. 2012, Németh et al. 2013/b). A rendelkezésre álló ismereteink szerint pedig valamennyi vele szomszédos földikutya kisfajtól reproduktívan izolálódott (Savic \& Soldatovic 1984, Savic et al. 2017). Jelenleg mindössze négy populációja ismert: (i) Újvidék közelében, a Fruska gora hegylábi területein; (ii) Szabadka, Kelebia és Ásotthalom külterületén, a szerb-magyar államhatár mindkét oldalán; (iii) Baja városának külterületén, valamint (iv) Albertirsa külterületén.

A bajai állomány 2013-as felfedezése éppen ezért óriási szenzációnak számított, hiszen megtalálásának idején ez volt a kisfaj harmadik ismert, egyszersmind messze legnagyobb egyedszámú állománya. A befogott (majd saját járataikba visszaengedett) bizonyító példányokon végzett genetikai vizsgálatok 2013 szept- 
emberére igazolták, hogy a populáció a délvidéki földikutyához tartozik. Ezzel pedig a kisfaj addig ismert világállománya megduplázódott (Csorba et al. 2015). A fennálló érdekek vizsgálata és a már elvégzett intenzív monitoring tevékenység eredményei alapján 2015-ben a Magyar Madártani és Természetvédelmi Egyesület a szakminiszternek címzett levelében kezdeményezte a populáció élőhelyén az országos jelentőségủ védett természeti terület létesítését. A sokrétủ szakmai munka eredményeként a Magyar Közlöny 2017. évi 29. számában kihirdetésre került a Bajai földikutya-rezervátum természetvédelmi terület létrehozását elrendelő miniszteri rendelet. Az összesen 114,252 hektár kiterjedésű védett területen a 2016-os felmérés szerint mintegy 350 példány délvidéki földikutya élt.

Azonban a védett terület határain kívül is bizonyossá vált a délvidéki földikutya előfordulása. Köztük egy olyan területen is, ahol rövid időn belül napelem-beruházási munkálatokat szándékoztak megvalósítani. A kivitelezés az ott élö állatok járatrendszereinek megsemmisülését, nagy valószínüséggel az egyedek pusztulását eredményezte volna. Ezért szükségessé vált a veszélyben lévő földikutyák számának felmérése, az állatok befogása és alkalmas, védett élőhelyre történő telepítése. Jelen cikkünk e munka bemutatását, valamint az áttelepített egyedek egy éves monitoringjának tapasztalatait, illetve az elvégzett természetvédelmi akció értékelését tárja az olvasó elé.

\section{Módszerek}

\section{Vizsgálati helyszín}

A jelen cikkben tárgyalt természetvédelmi beavatkozás Baja város északkeleti peremén, a Magyar Közlöny 2017. évi 29. számában kihirdetett Bajai földikutyarezervátum természetvédelmi területen illetve annak közvetlen közelében, a vele délről határos helyrajzi számokon zajlott (1. ábra). A Bajai földikutya-rezervátum területét nagy kiterjedésű, jó természeti állapotú homoki sztyepprét borítja, mely a délvidéki földikutya mellett még számos védett és fokozottan védett faj számára szolgál élőhelyül (Németh et al. 2016). Az áttelepítésben részt vevő egyedek befogására a Bajai földikutya-rezervátum közvetlen szomszédságában, nem védett területen került sor (1. ábra). E terület jelentősen zavart, degradált volt, a felszíni formák korábbi és jelentős talajmunkával járó beavatkozások, bolygatások nyomait mutatták. A közvetlenül egy energetikai beruházás (napelemfarm létesítése) előtt álló területen befogott példányok a Bajai földikutya-rezervátum egy távolabbi, annak keleti szélén fekvő kerültek elengedésre (1. ábra). A homoki sztyeppréttel borított gyepfoltot keleti és nyugati oldalról telepített nemes nyáras (Populus $x$ euramericana) határolja, a terület hasznosítása juhlegeltetéssel törté- 


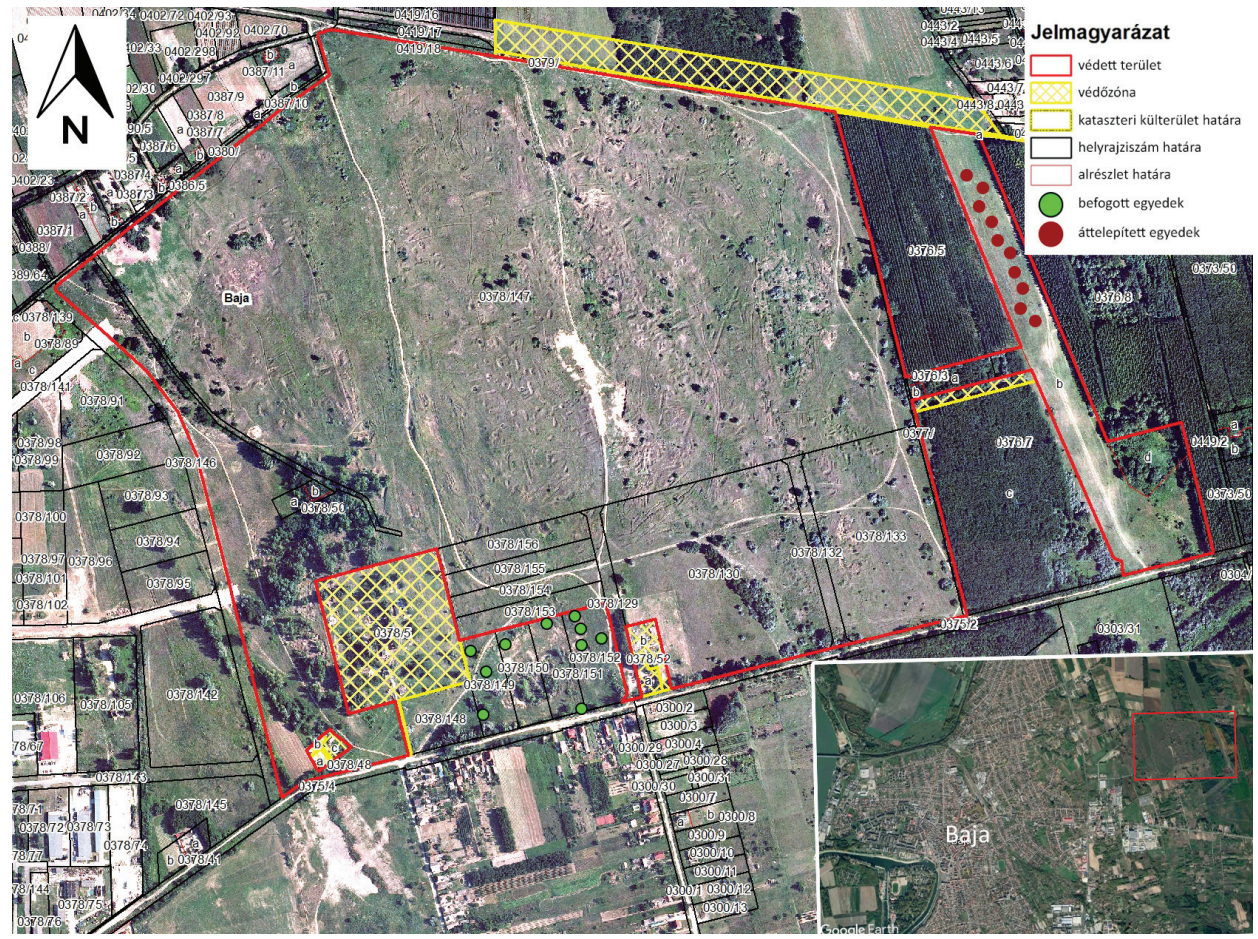

1. ábra: A Bajai földikutya-rezervátum természetvédelmi terület határai és védőzónája és a környező területek térképe, az áttelepített földikutyák befogási és szabadon bocsátási helyeinek feltüntetésével.

nik. A korábbi felmérések eredményei alapján, az akció kezdetekor a kiválasztott területet nem lakták földikutyák. A monitoring és a további vizsgálatok a Bajai földikutya-rezervátum ezen keleti részeire terjedtek ki.

\section{Az áttelepités módszertana}

Földikutyák (vagy más, hasonlóan szélsőséges talajlakó életmódot folytató kisemlősök) áttelepítésére alig volt példa mindeddig, az ismert, bármilyen módon dokumentált esetek mindegyike hazánkban történt. A földikutyák áttelepítése során alkalmazott módszert a Magyar Természettudományi Múzeum és a Hortobágyi Nemzeti Park Igazgatóság szakemberei együttesen dolgozták ki (Németh et al. 2013/c) és 2013-óta sikeresen alkalmazzák a Hortobágyi Nemzeti Park Igazgatóság müködési területén.

Az áttelepítési helyszínnel szemben támasztott egyik legfőbb követelmény, hogy az oda kerülő egyedek számára ökológiailag alkalmas legyen és hosszabb távon fenn tudja tartani a földikutya populációt. Ezért kiválasztása során szükséges alapos vizsgálatot végezni, mely kiterjed tájtörténeti, talajtani, botanikai és 
zoológiai felmérésekre, továbbá fontos a potenciális ragadozók jelenlétének becslése is (Németh et al. 2013/c). A környezeti és ökológiai tényezőknek azonosságot vagy legalábbis jelentős mértékủ hasonlóságot kell mutatniuk az eredeti élőhelylyel (Németh et al. 2013/c).

Egy életképes földikutya populáció létrehozásához megfelelö számú egyed szükséges és szem elött kell tartani az ivararányt is (Németh et al. 2013/c). A korábbi tapasztalatok szerint az állatok befogásának legmegfelelőbb időszaka az ősz (Moldován 2014). A befogások során a járatmegbontásos, kapás módszer (Németh et al. 2007) bizonyult a leghatékonyabbnak (Németh et al. 2013/c, Moldován 2014). A befogott egyedek átmeneti tartására a fajmegőrzési tervben találunk iránymutatást (Németh et al. 2013/a).

Valamennyi kézre került és áttelepített földikutyától genetikai mintát kell venni a létrehozandó új populáció genetikai változásainak nyomon követhetősége céljából. Továbbá, minden áttelepített példány a bőre alá ültetett mikrochip révén, egyedileg jelölést kap. Ennek köszönhetően a később felszínre tévedt és ott megtalált élő egyedek vagy az esetleg előkerülő tetemek azonosíthatók lesznek (Németh et al. 2013/c).

Mivel a földikutyák szélsőséges módon specializálódtak a talajlakó életmódra, ezért az egyedek egyszerü (felszíni) elengedése túl kockázatos lenne. Ennek tükrében a földikutyák az új élőhelyen a felszín alatt fél méteres mélységben kialakított mesterséges járatrendszerbe kerülnek elengedésre. Ezeknek az alagútrendszereknek biztosítaniuk kell mindazt, amikre a földikutyáknak a túléléshez szükségük lehet. A kialakított három kamra egyike nagy mennyiségü táplálékkal van megtöltve (táplálékraktár), egy másik puha száraz szénát tartalmaz (fészekkamra), míg a harmadik üresen marad (potenciális ürülék gödör). A kamrákat járatok kötik össze egymással. A mesterséges alagútrendszer úgy kerül kialakításra, hogy azt a földikutya később igényeinek megfelelően bővíteni tudja. Az egész járatrendszer körül fél méter mélyen a talajban és a talajfelszíntől mérten fél méter magasan kerítés húzódik, mely megakadályozza az esetlegesen a felszínre kerülő példányok vándorlását (Németh et al. 2013/c). A járatrendszer kiépítése az eddigi tapasztalatok szerint kulcsfontosságú az egész akció sikerességének szempontjából (Moldován 2014). Az egyedek mesterséges alagútrendszerbe történő elengedését követően az áttelepítési helyszínt 1-2 napig szükséges megfigyelni és őrzés alatt tartani, annak érdekében, hogy az esetlegesen bajba kerülő és a felszínre jövő példányokról gondoskodni lehessen (Németh et al. 2013/c).

\section{A monitoring módszertana}

A monitoring során az eddig legjobban dokumentált visszatelepítés módszertanát követtük. A Hajdúsági Tájvédelmi Körzet, Kék-Káló menti területének, bagaméri 
Malom-gát nevủ részére történt visszatelepítés egy éves utánkövetésének szisztémáját használtuk (Moldován 2014).

A megfigyelések keretében a földikutya járatrendszerének egyetlen felszín feletti részét, a túrásokat illetve azok mennyiségének és térbeli valamint időbeli eloszlásának változásait követtük nyomon. Az áttelepített egyedek elmozdulása, aktivitásának mértéke és változása, illetve az állomány egyedszáma jól követhető az általuk készített túrások számából illetve azok eloszlásából. A mintaként szolgáló módszertan - szakirodalmi elózmény hiányában - a gyakorlatban forrta ki magát, ezért mi a végső, letisztult eljárást alkalmaztuk (Moldován 2014). A túrások pozíciója kézi GPS készülékkel (Garmin Oregon 600) került rögzítésre. Az adatok térinformatikai feldolgozása és értékelése Quantum GIS program segítségével történt (QGIS Development Team 2013).

A földikutya egyedek elengedését követően (2017.10.14.) egy éven keresztül havonta legalább két alkalommal került sor a friss túrások pozíciójának rögzítésére. 2018 májusában és augusztusában technikai okokból kifolyólag csak havi egy felmérést végeztünk. Annak érdekében, hogy minden túrás csak egyszer kerüljön felmérésre, a már rögzített pozíciójú halmokat elsimítottuk. Mindez abban is segített, hogy az ugyanazon a helyen történő újbóli rátúrások is egyértelmüen észlelhetőek legyenek.

\section{Abiotikus és növényzeti háttéradatok}

Az eredmények és tapasztalatok helyes és megalapozott értékelése érdekében az áttelepítési helyszín adottságairól, jellemzőiről minél teljesebb képet igyekeztünk nyerni. Ehhez részben a terület tájtörténetének ismeretére volt szükség. Minderre az Első- (1783), a Második- (1858), és a Harmadik Katonai Felmérés (1881) térképlapjai, valamint a II. Világháború idején (1941) készült katonai térképezések nyújtottak lehetőséget.

Fontos volt továbbá a terület talajtani és domborzati jellemzőeinek megismerése is. Az érintett területek mikro-domborzatának vizsgálatához a Földmérési és Távérzékelési Intézet (FÖMI) 1:10000 EOTR térképe nyújtott segítséget. A térképészeti vizsgálatok során a Quantum GIS programot használtuk (QGIS Development Team 2013). A talajvízszint mélységének megállapításához és a talajszerkezet alapvető megismerése érdekében 2018. szeptember 15-én talajfúrásokat végeztünk az elengedési helyszínen. A mintavételezést 12 pontban, egymástól 30 méteres távolságokban végeztük kézi talajmintavevővel.

Mivel a földikutyák kizárólag növényi eredetű táplálékot fogyasztanak, ezért az áttelepítési helyszín növényzeti jellemzői minden bizonnyal hatással lehettek az új élőhelyen a monitoring során tapasztalt viselkedésükre és az áttelepített egyedek életére. Ehhez csak a már rendelkezésre álló növényzeti adatokat volt lehető- 
ségünk használni. A Kiskunsági Nemzeti Park Igazgatóság egyik belső vizsgálata különösen hasznosnak bizonyult. Sipos Ferenc botanikus 2018 augusztusában a Bajai földikutya-rezervátum földikutyák által lakott területén, valamint az állatok elengedési helyszínén három egy-egy hektáros mintaterületen végzett összehasonlító növényzeti vizsgálatot. Ennek eredményeit használtuk fel a monitoring során tapasztaltak értelmezéséhez.

\section{Eredmények}

Áttelepités

A 2017 tavaszán a napelem beruházással érintett terület földikutya állományának túráscsoportok számolása alapján végzett felmérése szerint a területen 10 példány délvidéki földikutya előfordulása volt valószínüsíthető. Ezeknek az egyedeknek a befogása és áttelepítése két szakaszban történt. Az első 7 példány (6 nőstény, 1 hím) 2017. október 3-5 között, majd a további 3 nőstény egyed transzlokációja 2017. október 16-17. között zajlott.

A földikutyák a kijelölt áttelepítési helyszín középvonalában nagyjából egy É-D-i egyenes mentén (a fajgazdagabb növényzeti foltokat követve, olykor cikkcakk mintázatban) egymástól mintegy 30 méteres távolságban kerültek elengedésre a számukra kialakított mesterséges járatrendszerekbe.

A befogásokat követően nem volt tapasztalható az újabb friss földikutya túrások megjelenése a napelem beruházás tervezett helyszínén. Ezáltal elmondható, hogy nem maradt délvidéki földikutya a veszélyeztetett területen.

\section{Monitoring}

A legelső felvételezés során (2017. október 14.) nyilvánvalóvá vált, hogy az első szakaszban szabadon engedett délvidéki földikutyák mindegyike túlélte az áttelepítést, mivel az egyedek nagyfokú aktivitást mutattak (2. ábra). A második szakaszban áttelepített 3 egyed közül egy hét elteltével kettő készített friss túrásokat. A hónap végére az elengedési helyszín nyugati oldalán három, míg a keleti oldalán egy helyen jutottak át a földikutyák a területet két oldalról határoló földutak alatt, majd a telepített nemes nyárasok felé vették az irányt. A 3-as számmal ellátott hím egyed meglehetösen messze távolodott a többiektöl.

November első felében az áttelepített földikutyák továbbra is aktívak voltak és sorra készítették a túrásokat. A friss halmok a felmérés szerint 6 egyedtől származhattak. Fontos kiemelni, hogy az elengedése óta még aktivitást nem mutató 10-es számú egyed is készített friss túrásokat ebben az időszakban. Az állatok további két ponton jutottak át a földút alatt. November végén csökkenő mértékben, 


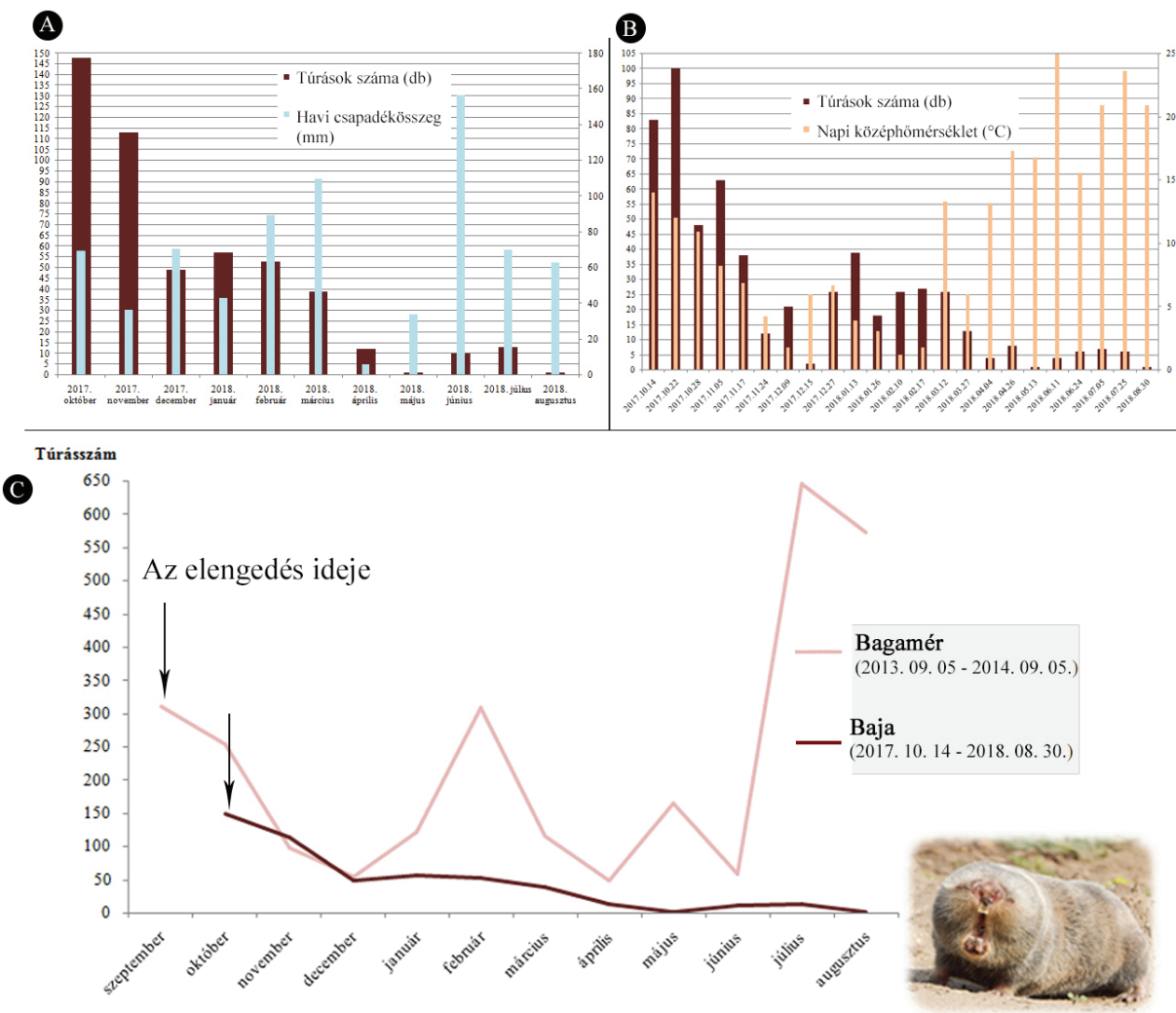

2. ábra: Az áttelepített földikutyák egyévnyi monitoringjának eredményei; Az áthelyezett egyedek aktivitásának alakulása a havi csapadékösszeg (A) és a felmérés idejének napi átlaghőmérsékletével (B) összevetve Alsó-Duna-Völgyi Vízügyi Igazgatóság által 2017 októbere és 2018 szeptembere között mért meteorológiai adatok alapján. Az ábra $\mathbf{C}$ részén a Baján áttelepített földikutyák aktivitás-mintázatának változása látható egy korábbi, sikeresnek ítélt, szintén homoki élőhelyen (Bagamér közelében) végzett földikutya-áttelepítés egyévnyi monitoringjának adatsorával együtt ábrázolva.

de továbbra is aktívak voltak a földikutyák. Sajnálatos módon november végétől azonban az 1-es, a 4-es, a 8-as és a 9-es számú egyedek többé már nem mutattak aktivitást, a későbbiekben már egyszer sem adtak életjelet magukról.

December elején 4, a hónap közepén pedig 2 egyed mutatott aktivitást. December végén ismét növekedett a túrásszám, ami január közepéig kitartott. Váltakozó intenzitású, de enyhén csökkenő aktivitás volt tapasztalható január és február során. Márciustól azonban a túrások számának nagymértékü csökkenése volt érzékelhetö. Március és április során feltételezhetően 3 vagy 4 egyed lehetett aktív a területen. Májusban egyetlen földikutyatúrás került regisztrálásra, amelyet feltéte- 
lezhetően a 10-es számú egyed készíthetett. Ettől a hónaptól kezdve a 7-es számú állat sem mutatott többé aktivitást.

Június és július során kissé nőtt az aktivitás, egy-egy felmérés során 4-6 friss túrást lehetett találni az áttelepítési helyszínen. Feltételezhetően ezek 2 vagy 3 egyedhez tartozhattak. Augusztus során ismét csupán egyetlen friss földikutyatúrás keletkezett a területen.

Az egyévesre tervezett monitoring 2018 öszén ért véget. A Bajai földikutyarezervátum 2018 novemberében elvégzett éves állományfelmérése alapján az áttelepítési helyszínen 2 példány földikutya jelenléte volt megállapítható. A monitoring tapasztalatok szerint az áttelepített földikutyák között nem történt párzás; a területen előforduló egyetlen hím számottevően eltávolodott a többi nősténytől, és később sem közelítette meg őket.

\section{Aktivitás időbeli változása}

Az elengedést követően az áttelepített földikutya egyedek rögtön új járatrendszerük kiépítésébe kezdtek. Mindez a monitoring során a rengeteg friss túrás megjelenése révén mutatkozott meg. Ez a nagyfokú aktivitás az ősz során egyre csökkent, egészen december közepéig. December végétől február közepéig ismét egy aktívabb időszak tapasztalható, ekkor kissé nőtt a területen megfigyelhető friss túrások száma. Ezt követően az aktivitás eltérő mértékü, de folyamatos csökkenése volt érzékelhető. Március közepéig enyhén csökkent a túrások száma, majd március-április során látványosan alábbhagyott az áttelepített földikutyák járatépítési kedve. A megfigyelt aktivitás mélypontja május hónap volt. Ezt követően június és július hónapokban ismét valamelyest több friss túrás volt megfigyelhető. Az aktivitás augusztusra újból a minimálisra csökkent.

\section{Aktivitás térbeli mintázata}

Az áttelepített földikutyák a azabadon engedésüktől fogva nagymértékü elmozdulásokat produkáltak. Több egyed már az elengedést követő első hónapban 3050 méterrel is eltávolodott szabadon bocsátásának helyétől. Elmozdulásaiknak az első időszakban nem volt kiemelt iránya, a különböző egyedek a szélrózsa minden irányába szétrajzottak. Némely egyed túrássorának láncolata szerint még decemberben is jelentős távolságot tett meg. Az áttelepített földikutyák a jelek szerint gond nélkül átjutottak a terület keleti illetve nyugati oldalán futó földút alatt. A földutak keresztezése számos alkalommal megtörtént, feltételezhetően több példánynak is sikerült. Ezt követően ezek az egyedek jellemzően a területet keletröl, illetve nyugatról határoló, egyben izoláló nemes nyárasokban kötöttek ki. Ezek a faültetvények szélébe jutó példányok az év első hónapjaiban jellemzően mind észak felé indultak meg. Az egyre inkább csökkenő aktivitás miatt a földikutyák 
felszín alatti tevékenységének további térbeli irányultsága már nem volt követhető. A nyár során jelent meg csupán egy összefüggő túrássor az elengedési helyszín délebbi részén, az 1-es és a 3-as számú példány mesterséges járatrendszere közötti területen.

\section{Értékelés}

A természetvédelmi beavatkozás eredményének értékelése

A Baja környékén végzett délvidéki földikutya-áttelepítési akció során a beruházási területen élő összes állat befogásra került. A transzlokáció kivitelezése is sikeresnek tekinthető hiszen, a monitoring eredményekből látszik, hogy a 10 áttelepített földikutyából 2017. év végéig valamennyi egyed mutatott aktivitást, vagyis nekikezdett saját, új járatrendszere kiépítésének. Így a veszélyeztetett élőhelyen lévő délvidéki földikutya egyedek megmentésére irányuló természetvédelmi beavatkozásnak a befogási és áttelepítési szakasza sikeresnek tekinthető.

Azonban a kimenekített állatok megtelepítése a kijelölt élőhelyen már sokkal kevésbé mondható sikeresnek. Míg 2018 januárjában még 6 földikutya mutatott rendszeres aktivitást, a monitoring adatok alapján 2018 augusztusában már csupán 2, maximum 3 egyed lehetett jelen a területen. Az akciót egy évvel követően pedig a 10 áttelepített földikutyából mindössze kettő volt megtalálható az elengedési helyszínen. Ezen adatok tükrében világos, hogy az áthelyezett állatok valamilyen okból kifolyólag eltűntek a számukra kiválasztott élőhelyről. A szerencsétlen végkifejlethez több tényező is vezethetett, a lehetséges okok feltárása pedig kulcsfontosságú. Mivel a transzlokációk tervezése és kivitelezése során a kijelölt áttelepítési helyszín alkalmassága fontos kérdés, ezért a probléma megvitatása és a lehetséges okok azonosítása, a jövőbeli hasonló akciók szempontjából is nagy jelentőséggel bír.

\section{Az áttelepitett egyedek viselkedése a korábbi tapasztalatok tükrében}

A monitoring eredmények értékeléséhez jó összehasonlítási anyagnak bizonyultak a korábbi áttelepítések utánkövetésénél gyüjtött eredmények. A legelső földikutya transzlokációt 2013-ban erdélyi földikutya, Nannospalax (leucodon) transsylvanicus kisfajjal végezték. Az egyedeket a hajdúhadházi populációból a Hajdúsági Tájvédelmi Körzethez tartozó bagaméri Malom-gát területre telepítették. A terület a bajai élőhelyhez hasonlóan homokpuszta, amit száraz homoki gyepek borítanak.

Bagamérban az állatok áthelyezését követően már az első napokban keletkeztek friss túrások (Moldován 2014) csakúgy, mint a bajai délvidéki földikutyák 
esetében. Mindez arra utal, hogy az elengedett földikutyák új járatrendszerük kiépítésébe kezdtek. A bagaméri egyedeknél december közepéig csökkenő túrásszám volt tapasztalható, de decembertől februárig látványosan megnövekedett az aktivitás (Moldován 2014). A bajai földikutyáknál december közepéig a túrások száma fokozatosan csökkent, majd enyhe növekedésnek indult. A halmok számának látványos növekedése az év első hónapjaiban a szakirodalom szerint egyértelmüen a párzási időszakhoz köthető (Vásárhelyi 1926). A földikutyák ilyenkor elkezdik aktívan keresni fajtársaikat, ennek eredménye a sok friss túrás megjelenése az élőhelyeken. Ennek megfelelően Baján is enyhén emelkedni kezdett a túrásszám 2017. decemberének végétől, de mindez január közepétől már ismét enyhe csökkenésbe fordult át, ami 2018. márciusáig tartott. A bagaméri állatok aktivitásában februártól látványos csökkenés mutatkozik (Moldován 2014), a bajaiaknál ez visszafogottabb mértékben, de szintén tapasztalható volt. Az egyedek aktivitása azonban Baján áprilisban sem emelkedett, a márciusban kezdődött drámai lejtmenet tovább folytatódott. Az aktivitás ilyen mértékủ csökkenése a vegetációs időszak elején aggasztó tendenciát sejtet. Mindezt alátámasztja, hogy 2018. áprilisának közepén Öttömösön - ahol ugyancsak új földikutya állomány létrehozása zajlik - az áttelepített szintén délvidéki földikutyák nagymértékü aktivitást mutattak (a szerzők személyes megfigyelése). A bagaméri egyedek aktivitása májusra ismételten jelentősen növekedett (Moldován 2014), szemben a Baja környékén áthelyezett állatokkal, akik ebben a hónapban mutatták az addig tapasztalt legalacsonyabb aktivitást, mindössze egyetlen friss túrással. Az Albertirsa közelében lévő délvidéki földikutya állományban a tavaszi terepmunkák során 2018. májusának elején szintén szép számban megtalálhatóak voltak friss túrások, az egyedek aktívak voltak (a szerzők személyes megfigyelése). Bagamér környékén a földikutyák a nyári hónapokban (júniustól augusztusig) nagy mennyiségủ friss túrást produkáltak, mely valószínűleg a helyben született fiatal egyedek önálló járatrendszereinek építésével függhetett össze (Moldován 2014). Baján júniusban és júliusban végig alacsony volt az aktivitás, míg augusztusra ez ismét havi egyetlen friss túrásra csökkent le.

Az áttelepítési eseményeket követően - annak ellenére, hogy eltérő földikutya kisfajhoz tartoznak - a két területen kezdetben nagyon hasonlóan viselkedtek az állatok. Az aktivitás intenzitásának hasonló mintázata elengedést követő első tavaszig volt megfigyelhető. Ugyanakkor a tavasz során a bajai helyszín földikutyái a Bagamérban tapasztaltaktól nagyfokú eltérést mutattak. Az egyedek aktivitása és a halmok száma ettől fogva szinte folyamatosan csökkent. Azonban ha nem csupán a túrásszám növekvő vagy csökkenő trendjét figyeljük, hanem az aktív periódusok aktivitási csúcsainak méretét is összevetjük egymással (2. ábra), akkor világosan látszik, hogy a bajai állomány esetében a gondok már 2017. decemberé- 
ben elkezdőtek. Míg Bagamérban a január-februári aktív időszakban a keletkezett túrások száma eléri az elengedés után közvetlenül tapasztalt túrásmennyiséget, addig a bajai helyszín esetében még csak meg sem közelíti azt. Vagyis a Baja környékén áttelepített állomány problémái az első igazi hidegek beköszöntével jelentkeztek.

Bár a Bajánál áttelepített egyedek drámai fogyatkozásának okát, akár kereshetnénk a 2018-as év tavaszának a szokásostól nagy mértékben eltérő időjárásában is. Ugyanakkor a két áttelepítés monitoring adatainak összehasonlítása révén világosan látható, hogy a problémák jóval korábban, már a tél során megkezdődtek (2. ábra). Ráadásul a többi megfigyelt állományok (köztük szintén áttelepítéssel létrehozottak) egyikében sem volt tapasztalható 2018. tavaszán az egyedek aktivitásának a bajai áttelepítési helyszínen megfigyelthez hasonló változása. Az adatok alapján tehát úgy látszik, hogy önmagában a szokatlan időjárás nem okolható az állatok eltünéséért.

Az áttelepitési helyszín abiotikus és növényzeti jellemzőinek értékelése

Az Első Katonai Felmérés térképén (1783) a bajai áttelepítés helyszíne szántóként látható (Arcanum 2004), majd a 19. század közepén a Második Katonai Felmérés során (1858) már pusztaként jellemezték. Ugyanakkor az ebben az időszakban készült térképen jelölték a terület esetleges magasabb vízellátottságát is, hiszen jelentős részét vízhatás alatt álló, nedves kaszálóként ábrázolják. Rózsás (2007) a Debrecen-Józsai földikutya élőhely tájtörténeti vizsgálata során ezt a földikutyák számára nem ideális, szuboptimális élőhelytípusnak találta. A területet az 1880-as évek elején ritkás náddal foltozott legelőként ábrázolják. A II Világháború idején készült térképen (1941) részben szántóként, részben ritka nádassal borított füves rétként van feltüntetve. Ezek alapján elmondható, hogy az egykor szántóként is müvelt területet az időnként jellemző magasabb vízellátottság következtében olykor nedves, ritkás náddal borított rét fedte. Ezzel ellentétben a Bajai földikutya-rezervátum földikutyák által lakott törzsterületének legnagyobb részét az Első Katonai felmérés idejétől napjainkig folyamatosan száraz gyep borította. Az áttelepítési helyszínen végzett talajfúrások eredményei azt mutatják, hogy a talajvíz szintje napjainkban is igen magas. A tíz elengedett földikutya egyedből öt olyan helyen lett szabadon bocsátva, ahol ez akár tényleges problémát is okozhatott. A földikutyák élőhelyi igényeinek talajtani, domborzati aspektusait vizsgáló kutatások eredményei azt mutatják, hogy az állatok azokat a területeket preferálják, ahol a téli időszakban kellő mélységig - a talajvíz szintje felett maradva -le tudnak húzódni (Nyárády et al. 2016). A legtöbb - különösen a homokvidékeken található - földikutya előfordulási helyről elmondható, hogy domborzatilag változatosak (kisebb-nagyobb buckákkal tarkítottak) (Németh et al. 2013/a). A FÖMI 
EOTR térképének szintvonalas ábrázolása jól mutatja a Bajai földikutya-rezervátum törzsterületének és az áttelepítésre kijelölt részének különbségét. Az áthelyezett példányok alacsonyabb térszínü, valamint domborzatilag kevésbé változatos helyre kerültek. Így fennállhatott az a veszély, hogy a téli csapadékos időszakban a magas talajvízszint és a kevéssé tagolt domborzat következtében az állatok képtelenek voltak megfelelő téli menedéket találni. Mindezek együttesen, akár hozzá is járulhattak bizonyos egyedek eltünéséhez, esetleges pusztulásához.

A Bajai földikutya-rezervátum teljes körü vegetáció-térképezésére és reprezentatív cönológiai felmérésére mindeddig nem került sor. Az eddigi legátfogóbb, a Kiskunsági Nemzeti Park Igazgatóság belső vizsgálataként született felmérés eredményei ugyanakkor esetünkben jól használhatóak. A Sipos Ferenc botanikus által 2018. augusztusában a Bajai földikutya-rezervátum földikutyák által lakott területén, valamint az áttelepített egyedek elengedési helyszínén három, egyenként egy-egy hektáros kijelölt mintaterületen végzett vegetáció felmérést. Az 1-es számú mintaterületen (ahol az állatok elengedésre kerültek) a legnagyobb tömegben előforduló faj a csillagpázsit (Cynodon dactylon) volt. A vizsgálat megállapítása szerint a csillagpázsit, mint erős és kemény tarackú pázsitfüféle fizikai akadályt jelenthetett a földikutyák számára, ezáltal kedvezőtlenül hatva az áttelepített egyedekre (Sipos 2018 - publikálatlan adat). Ugyanakkor számos élőhelyen élnek földikutya egyedek olyan foltokban, ahol az uralkodó füféle a csillagpázsit. Továbbá a 2018. októberében Öttömösre történő áttelepítés során a példányok befogásakor előkerült olyan táplálékraktár, melyben a legjelentősebb gyüjtött növényi rész a csillagpázsit tarackja volt (a szerzők személyes megfigyelése). Az 1-es számú területen a vizsgálat során a botanikus 51 növényfajt észlelt, ebből 29-et említ meg lehetséges földikutya táplálékként. Feltételezhetően ez a juhlegeltetéssel hasznosított gyep a legrövidebb ideje felhagyott szántó a Bajai földikutya-rezervátum területén. A második mintaterület a Bajai földikutya-rezervátum észak-keleti részén található. Az éves állományfelmérések korábbi eredményei azt mutatják, hogy ezen a területen alacsony a földikutyák egyedsürüsége. Az észlelt növényfajok száma 54, ebből 33 tekinthető lehetséges földikutya tápláléknak. A harmadik mintaterületen előforduló nagyszámú sztyeppréti növényzet jól mutatja, hogy a korábbi szántó felhagyása itt történhetett meg a leghamarabb. Az éves állományfelmérések korábbi eredményei szerint ezen a területen jelentős a földikutyák egyedsürúsége. A legnagyobb tömegben előforduló pázsitfüféle a pusztai csenkesz (Festuca rupicola). Az észlelt fajszám 62, amelyből 42 lehet potenciális tápnövény a földikutyák számára. A vizsgálat eredményei szerint a délvidéki földikutyák elengedési helyszínén a gyom (18) és a zavarástürő (17) fajok fordultak elő a legnagyobb számban. A természetes állapotra utaló fajok közül a kísérő 11 , a társulásalkotó 3 , míg a pionír fajok száma 2 volt. Az elemzés során 
jól látszott, hogy a három vizsgált mintaterület közül az áttelepítés helyszínén volt a legkevesebb növényfaj. Mindez igaz a földikutyák számára lehetséges tápnövények számát illetően is. A Simon-féle Magyarországi edényes flóra határozójában (Simon 2000) található Természetvédelmi Érték Kategóriákat (TVK) követve látható, hogy mindhárom mintaterület esetében a degradációra utaló fajok aránya a domináns. A százalékos megoszlás alapján ugyanakkor elmondható, hogy az áttelepítési helyszínnél a legnagyobb a degradációra utaló fajok aránya, míg a természetes állapotot jelzőké itt a legkisebb. Érdemes megjegyezni, hogy mivel mindkét a Bajai földikutya-rezervátum törzsterületén fekvő mintaterület közvetlenül határos hosszú ideje háborítatlan, népes földikutya állománnyal rendelkező gyepekkel, ezért nem jelenthető ki egyértelmüen, hogy a földikutyák rajtuk megfigyelhető jelenléte bizonyosan az élőhely alkalmasságát mutatja. Elméletileg a népesebb földikutya állománynak otthont adó, természetes gyepekről kiszoruló egyedek folyamatos megtelepedési próbálkozásai is okozhatják a területeken megfigyelhető állandó földikutya jelenlétet. Ennek ellenőrzése azonban további megfigyeléseket igényelne. Az elvégzett botanikai vizsgálatok mindenesetre azt mutatják, hogy a kijelölt áttelepítési helyszín a földikutyák számára növényzeti szempontból sem tekinthető ideálisnak.

\section{Monitoring eredmények értelmezése a háttéradatok ismeretében}

Az utánkövetés eredményei alapján az egyedek időbeli aktivitását a háttéradatok - vagyis az elengedésre kijelölt helyszín jellemzőinek - ismeretében értelmezve úgy tủnik, hogy a kezdeti, minden bizonnyal a járatrendszer kiépítéséhez illetve élelemgyüjtéshez köthető fokozott aktivitás után a problémák a tél beálltakor és az első hidegek jelentkezésekor mutatkoztak. A monitoring adatok alapján az egyedek térbeli aktivitását vizsgálva szemebtünő, hogy a földikutyák meglepően nagy elmozdulásokat produkáltak ebben az időszakban. Úgy tünt, mintha alkalmas és kellően táplálékbő élőhelyfoltot kerestek volna. Feltételezhetően az áttelepített példányoknak nem sikerült kellő mennyiségü táplálékot összegyüjteni és elraktározni a téli időszakra vagy esetleg a megemelkedő talajvízszint is problémát okozhatott egyes egyedek számára. Az minden bizonnyal kijelenthető, hogy a párzási időszakban már nem volt megfigyelhető a bagaméri állomány monitoringja alapján várható intenzitású aktivitás. A még egyáltalán aktív állatok fokozatosan É-ÉNy-i irányba mozogtak, és a nyáras facsoport északról történő kikerülésére törekedtek. Ezek a mozgásmintázatok arra engednek következtetni, hogy a földikutyák - valószínüleg alkalmasabb élőhelyet keresve maguknak - megpróbálták elhagyni a helyszínt. Feltételezhetően egyes egyedek megkísérelték megkerülni a számukra akadályt képező - egyébként a területet határoló és egyben izoláló erdőtömböt. Valószínüleg a tavasz során a még a területen lévő egyedek utolsó 
tartalékai is kimerültek, mely helyzetük közepette a 2018 tavaszára jellemzö, a szokásostól jócskán eltérő időjárás, csak további gondokat okozhatott. Év végére a felmérések szerint csupán két példány maradt az élőhelyen. Mindez esetleg utalhat arra is, hogy ez a kedvezőtlen adottságú, táplálékszegény élőhely valószínúleg csak nagyon kisszámú földikutya állomány eltartására képes.

\section{Földikutya szempontú élőhelykezelés lehetöségei}

Az áttelepített egyedek monitoring eredményei (térbeli elmozdulásaik és időbeli aktivitásuk csökkenése) illetve az előzőekben vizsgált domborzati, talajtani, valamint botanikai szempontok alapján határozottan úgy tủnik, hogy az elengedési helyszínnek kijelölt terület nem kifejezetten alkalmas a földikutyák számára. Az áttelepítéssel létrehozott állomány folyamatos csökkenése és eltünése valószínűleg jobban magyarázható a terület alkalmatlanságával, semmint a 2018-as év során megfigyelhető szokatlan időjárási eseményekkel. Az áttelepítés révén létrehozott töredékpopuláció felmorzsolódása a jelek szerint már 2017-2018. telén megkezdődött.

Amennyiben a kijelölt élőhely nem megfelelő - de legalábbis nem ideális - a földikutyák számára, jogos kérdésként merülhet fel, hogy különféle természetvédelmi beavatkozások, kezelések révén alkalmasabbá lehetett volna tenni. Ennek kérdése (a kijelölt élőhellyel kapcsolatos bizonytalanságokkal együtt) felmerült a Földikutya- és Ürgevédelmi Szakértői Csoport 2017. évi mindkét megbeszélésén. Esetleges megoldásként az áttelepítési helyszín a törzsállománnyal történő, zöldfolyosó kialakítása révén megvalósuló összeköttetésének gondolata merült fel. További lehetőségként szóba került még az elengedési helyszín kopár területein megvalósuló lucernavetés is. A zöldfolyosó lehetővé tette volna, hogy az elengedési terület alkalmatlansága esetén az egyedek a jelenleg is földikutyák által lakott, biztosan alkalmas gyepek felé elmozdulhassanak. A lucernavetés pedig a rendelkezésre álló táplálék mennyiségéhez tudott volna jelentős mértékben hozzájárulni. Sajnos jelen írás elkészítéséig egyik kísérlet megvalósítására sem került sor. (A zöldfolyosó kialakítása érdekében a szükséges erdősáv letermelése 2018 augusztusában megtörtént, de a terület viszonyai még nagyon távol állnak attól, hogy zöldfolyosóként müködhessen a földikutyák számára).

\section{Alternativ megoldások lehetösége}

További kérdésként merülhet fel, hogy ha a kiválasztott élőhely nem ideális a földikutyák számára, voltak-e alternatív lehetőségek az állatok máshova telepítésére. Az áttelepítési helyszín kijelölésének kérdése, még az áttelepítési akció tervezésének időszakában, a Földikutya-és Ürgevédelmi Szakértői Csoport tagjait is mélyen megosztotta. Az áttelepítési helyszín kijelölését élénk szakmai vita előzte 
meg 2017-ben. Két alternatív terület lehetősége - egy Öttömös és egy Madaras közelében fekvő - merült fel a bajaival szemben.

Az Öttömös határában, a KNPI vagyonkezelésében álló helyszínre már Kelebia térségéből kerültek délvidéki földikutyák. Az esetleges genetikai keveredés miatt a Bajáról származó egyedek ide való áthelyezése csak megalapozó vizsgálatok és előzetes kísérletek kedvező eredményei esetén lett volna szakmailag támogatható a Szakértői Csoport álláspontja szerint.

Potenciális áttelepítési területként és egyben alternatív megoldásként merült fel továbbá a Bajától délnyugatra, mintegy harmincöt kilométerre fekvő Madaras község határában található löszgyep is. A településtől délre, délkeletre található 2017-ben csupán Natura 2000 oltalom alatt álló (de azóta országos védelemben is részesült) - „Marhajárás-puszta” a Duna-Tisza köze egyik rendkívül értékes területe. A gyep talaja homokos lösz, ennek megfelelően átmenetet mutat a löszpuszta és a homoki sztyepprét között. A számos botanikai és zoológiai értéknek otthont adó terület hasznosítása juhlegeltetéssel történik. 2017 nyarán a kutatók kis csoportja, köztük jelen publikáció több szerzője a bajai földikutya élőhelyen, valamint Madarason talajtani vizsgálatokat végzett. A gyüjtött talajmintákból kiderült, hogy a bajai talaj típusa futóhomok és humuszos homok, a madarasié pedig kétféle csernozjom és humuszos homok. A talaj fizikai féleségét tekintve a madarasiak kötöttebbnek bizonyultak. Az itt fúrt minták esetében megfigyelhetö, hogy a vastag talajrétegen keresztül nincsen strukturális különbség, amely a földikutyák számára kedvező tényező (Nyárády et al. 2016). A területen kis mértékben, de fellelhetőek a bajaihoz rendkívül hasonló, vagy azzal azonos tulajdonságú talajok is. A két terület növényvilágát tekintve is sok egyezést találunk. A földikutyák potenciális tápnövényei tekintetében a bajai élőhely sok fajjal rendelkezik a Madarason elöfordulóak (Csathó 2009) közül.

Összefoglalva tehát a madarasi helyszín előnye volt, hogy egy új állomány létrehozása növeli a faj fennmaradási esélyeit, és a keveredés veszélyét is kiküszöböli, illetve valamiféle védettséget élvez, hiszen Natura 2000 terület (bár a földikutyák nem szerepelnek az élőhelyvédelmi irányelv mellékletein). Hátránya volt, hogy a talajtani viszonyok némileg eltérnek a befogás helyszínétől. A hazai jogszabályok szerint nem védett a terület és önkormányzati tulajdonban van, így a hosszú távú fenntarthatóság emiatt bizonytalanabb lehet. A célterület végső kiválasztásának legfontosabb szempontja az volt, hogy a bajai helyszín védelem alatt állt szemben a madarasival. (Meg kell jegyezni, hogy időközben megtörtént a Madarasi Marhajárás országos védett természeti területté nyilvánítása.) 


\section{Tanulságok}

Jelen publikációban bemutatott természetvédelmi akció, valamint az áttelepített földikutyák monitoring-eredményeinek legfontosabb tanulsága, hogy amennyiben sikeres földikutya-áttelepítésre törekszünk, akkor a jogi környezet adta adottságokat nem szabad az ökológiai, biológiai szempontok elé helyezni. Hiába kedvező egy terület jogi adottsága, ha az ökológiai jellemzőit tekintve kevéssé ideális a földikutyák számára. Az ökológiai feltételek megváltoztatása ugyanis sokkal kevésbé kivitelezhető, mint a jogi helyzet kedvező irányba történő befolyásolása vagy módosítása.

Köszönetnyilvánitás - Köszönettel tartozunk a Kiskunsági Nemzeti Park Igazgatóságnak valamint a Pest Megyei Kormányhivatal Környezet és Természetvédelmi Főosztályának, hogy lehetöséget biztosított a bemutatott vizsgálatok elvégzésére (PE-KTF/2424-5/2017). Hálásan köszönjük Sipos Ferencnek (KNPI), hogy rendelkezésünkre bocsátotta a növénytani felmérés során szerzett adatait. Köszönettel tartozunk Tamás Ádám természetvédelmi őrkerület-vezetőnek (KNPI), Kalocsa Bélának (MME) valamint Feldrihán Péternek az áttelepítés és a monitoring során a terepen nyújtott pótolhatatlan segítségükért. Hasonlóképp hálával tartozunk Dr. Csorba Gábornak és a Magyar Természettudományi Múzeumnak az áttelepítés kivitelezése és a monitoring során nyújtott pótolhatatlan segítségért. Végül köszönetet mondunk Rab Ferencnek (ADUVIZIG), hogy a Baja környékén mért meteorológiai adatokat munkánk felhasználáshoz biztosította.

\section{Irodalomjegyzék}

Barnosky, A. D., Matzke, N., Tomiya, S., Wogan, G. O., Swartz, B., Quental, T. B., Marshall, C., McGuire, J. L., Lindsey, E. L., Maguire, K. C., Mersey, B. \& Ferrer, E. A. (2011): Has the Earth's sixth mass extinction already arrived? - Nature 471: 51-57. doi: https://dx.doi.org/10.1038/nature09678

Ceballos, G., Garcia, A. \& Ehrlich, P. R. (2010): The sixth extinction crisis: Loss of animal populations and species. - J. Cosmology 8: 1821-1831.

Ceballos, G., Ehrlich, P. R., Barnosky, A. D., García, A., Pringle, R. M. \& Palmer T. M. (2015): Accelerated modern human-induced species losses: Entering the sixth mass extinction. $-S c i . A d v$. $1, \mathrm{e} 1400253$.

Ceballos, G., Ehrlich, P. R., \& Dirzo, R. (2017): Biological annihilation via the ongoing sixth mass extinction signaled by vertebrate population losses and declines. - P. Natl. A. Sci. A. 114, E6089E6096. doi: https://dx.doi.org/10.1073/pnas.1704949114

Csathó, A. I. (2009): A madarasi Marhajárás. Hol az a táj szab az életnek teret, Mit az Isten csak jókedvében teremt" - Válogatás az első tizenhárom MÉTA-túrafüzetből 2003 - 2009. MTA Ökológiai és Botanikai Kutatóintézete, Vácrátót, pp. 248-253.

Csorba, G., Krivek, G., Sendula, T., Homonnay Z. G., Hegyeli, Zs., Sugár, Sz., Farkas, J., Stojnić N. \& Németh, A. (2015): How can scientific research change conservation priorities? - A review 
of decade-long research on blind mole rats (Rodentia: Spalacinae) in the Carpathian Basin. THERYA. 6: 103-121. doi: https://dx.doi.org/ 10.12933/therya-15-245

Griffith, B., Scott, J. M., Carpenter, J. W. \& Reed, C. (1989): Translocation as a species conservation tool: Status and strategy. - Science 245: 477-480.

Hadid, Y. Németh, A., Snir, S., Pavlíček, T., Csorba, G., Kázmér, M., Major, Á., Mezhzherin, S., Rusin, M., Coşkun, Y. \& Nevo, E. (2012): Is evolution of blind mole rats determined by climate oscillations? - PLoS One 7: e30043. doi:https://dx.doi.org/10.1371/journal.pone.0030043

Hallmann, C. A., Sorg, M., Jongejans, E., Siepel, H., Hofland, N., Schwan, H. \& Goulson, D. (2017): More than 75 percent decline over 27 years in total flying insect biomass in protected areas. - PloS One 12: e0185809. https://doi.org/10.1371/journal.pone.0185809

Moldován, O. (2014): Az erdélyi földikutya Nannospalax (leucodon) transsylvanicus új populációjának létrehozása és az első év tapasztalatai. - Diplomamunka, Debreceni Egyetem, Debrecen, 44. p.

Németh, A., Czabán, D., Csorba, G. \& Farkas J. (2007): Egy fokozottan védett emlős, a nyugati földikutya (Spalax leucodon) csapdázásának lehetőségei. - Termvéd Közlem. 13: 439-444.

Németh, A., Csorba, G., Farkas, J., Krnács, Gy., Molnár, A., Boldogh, G. \& Szelényi, B. (2013/a): VM Fajmegörzési tervek: Kárpát-medencei Nyugati földikutya kisfajok (Nannospalax (superspecies leucodon)). - VM Környezetügyért Felelős Államtitkárság, Budapest. 68 p. doi: https:// dx.doi.org/10.13140/RG2.2.25180.59529

Németh, A., Krnács, Gy., Krizsik, V., Révay, T., Czabán, D., Stojnic, N., Farkas, J. \& Csorba, G. (2013/b): European rodent on the edge: status and distribution of the Vojvodina blind mole rat. SpringerPlus 2013 2:2. doi: https://dx.doi.org/10.1186/2193-1801-2-2

Németh, A., Molnár, A., Szél, L., Horváth, T., Demeter, L. \& Csorba, G. (2013/c): Hogyan telepítsünk át földikutyát? Módszertani megfontolások szélsőségesen talajlakó rágcsálók megmentéséhez - Termvéd Közlem. 19: 15-33.

Németh, A., Tamás, Á., Krnács, Gy., Vajda, Z., Sipos, F. \& Dóka, R. (2016): Baja földikutyarezervátum országos jelentöségü védelemre tervezett természetvédelmi terület természetvédelmi kezelési terve. - Kiskunsági Nemzeti Park Igazgatóság. Kecskemét. 25 p.

Nyárády, M., Sendula, T., Szalai, Z., Pásztor, L. \& Farkas J. (2016): Adatok a földikutya előfordulását befolyásoló talajtani paraméterekről. - In: Csorba, G., Kovács-Hostyánszki, A., Németh, A., Szepesváry, Cs., Vili, N. (szerk.) „Zászlóshajók, karizmák és esernyők: mit tehet az emlőskutatás a természetvédelemért" X. Magyar Természetvédelmi Biológiai Konferencia, Mühelytalálkozó, Absztrakt-kötet, Magyar Biológiai Társaság, 2016. 23 p.

Pereira, H. M., Leadley, P. W., Proença, V., Alkemade, R., Scharlemann, J. P., Fernandez-Manjarrés, J. F., Araújo, M. B., Balvanera, P., Biggs, R., Cheung, W. W., Chini, L., Cooper, H. D., Gilman L., Guénette S., Hurtt, G. C., Huntington, H. P., Mace, G. M., Oberdorff, T., Revenga, C., Rodrigues P., Scholes, R. J., Sumaila, U. R. \& Walpole, M. (2010): Scenarios for global biodiversity in the 21st century. - Science 330: 1496-1501. doi: https://dx.doi.org/10.1126/science.1196624

Pimm, S. L., Russel, G. J., Gittleman, J. L. \& Brooks, T. M. (1995): The future of biodiversity. - Science 269: 347-350.

Pullin, A. S., \& Bajomi, B. (2008): Are we doing more good than harm? Evaluating effectiveness of nature restoration policy in Europe. - In: Sixth European Conference on Ecological Restoration, Ghent, Belgium. 1-5.

QGIS Development Team (2013): QGIS Geographic Information System. Open Source Geospatial Foundation Project. http://qgis.osgeo.org

Rózsás, A. (2007): Első adatok a fokozottan védett, veszélyeztetett, nyugati földikutya (Spalax leucodon) hazai állományainak élőhelyi igényeiről. - Szakdolgozat, ELTE, Budapest, 88 p. 
Savić, I., Ćirović, D., \& Bugarski-Stanojević, V. (2017): Exceptional Chromosomal Evolution and Cryptic Speciation of Blind Mole Rats Nannospalax leucodon (Spalacinae, Rodentia) from South-Eastern Europe. - Genes 8: 292. doi: https://dx.doi.org/10.3390/genes8110292

Savić, I. \& Soldatović, B. (1984): Karyotype evolution and taxonomy of the genus Nannospalax Palmer 1903, Mammalia, in Europe. Separate edition of the Serbian Academy of Science and Arts. Beograd, 560. 104 p.

Seddon, P. J., Armstrong, D. P. \& Maloney R. F. (2007): Developing the science of reintroduction biology. - Conserv. Biol. 21: 303-312. doi: https://dx.doi.org/10.1111/j.1523-1739.2006.00627.x

Simon, T. (2000): A magyarországi edényes flóra határozója. - Nemzeti Tankönyvkiadó Rt., Budapest, 975. p.

Tóthmérész, B. (2018): Biodiverzitás és ökológia. - In. Tardy, J, Dévai, Gy. (szerk): A biodiverzitásról másképp. Magyar Természettudományi Társulat, Budapest, pp. 28-33.

Vásárhelyi, I. (1926): Adatok a földikutya (Spalax hungaricus hungaricus Nhrg.) életmódjának ismeretéhez. - Állattani Közlem. 23: 169-226.

Vida, G. (2018): Csökkenő biodiverzitás, növekvő gazdaság. Meddig? - In. Tardy, J, Dévai, Gy. (szerk): A biodiverzitásról másképp. Magyar Természettudományi Társulat, Budapest, pp. 14-25.

Internetes térképforrások

I. Katonai Felmérés (1782-85): HM Hadtörténeti Intézet és Múzeum Térképtára, Arcanum Adatbázis Kft., Budapest. http://mapire.eu/hu/map/firstsurvey/

II. Katonai Felmérés (1806-1869): HM Hadtörténeti Intézet és Múzeum Térképtára, Arcanum Adatbázis Kft., Budapest. http://mapire.eu/hu/map/secondsurvey/

III. Katonai Felmérés (1869-1887): HM Hadtörténeti Intézet és Múzeum Térképtára, Arcanum Adatbázis Kft., Budapest. http://mapire.eu/hu/map/thirdsurvey25000/

II. Világháborús Katonai Felmérés (1941): HM Hadtörténeti Intézet és Múzeum Térképtára, Arcanum Adatbázis Kft., Budapest. http://mapire.eu/hu/map/hungary1941/

Kataszteri térképek (XIX. század): http://mapire.eu/hu/map/cadastral/ (Arcanum Adatbázis Kft., Budapest)

Fentröl.hu: $\quad$ https://www.fentrol.hu/hu/. (FÖMI, BFKH Budapest) Magyarország EOV topográfiai térképezése. 1980-as évek, méretarány 1:10 000 (FÖMI, $\mathrm{BFKH})$. 


\section{Lessons to be learn from a blind mole rat translocation}

\section{Viktor Schneider ${ }^{1}$, János Ruzsa ${ }^{2}$, Dávid Czabán ${ }^{2}$ and Attila Németh ${ }^{3}$}

${ }^{1}$ Szent István University, Faculty of Agriculture and Environmental Sciences, H-2100 Gödöllö, Páter u. 1., Hungary

${ }^{2}$ Independent researcher

${ }^{3}$ Hungarian Natural History Museum, H-1088 Budapest, Baross u. 13., Hungary

E-mail:viktor.schneider95@gmail.com

Near to the Bajai földikutya-rezervátum protected area (Blind mole rat Reserve of Baja), the home of the largest known population of Vojvodina blind mole rat, it became necessary to translocate a small population of blind mole rats from a solar power plantation construction site. In the course of the conservation action carried out in 2017. ten individuals were translocated to a part of the protected area, which was not inhabited by blind mole rats that time. After the translocation, the animals were monitored for a year. Comparing the results of the monitoring with data of observation of an already finished, successful translocation, an unfavourable trend was noticed. When various ecological features (relief, soil, botany) of the capture and release sites were compared, the incapability of the designated release site is also arise. The presented results can hopefully contribute to the success of similar future translocation actions.

Keywords: Nannospalax (leucodon) montanosyrmiensis, habitat requirements, habitat suitability, monitoring, Baja 